\title{
Nutraceutical Content and Daily Value Contribution of Sweet Potato Accessions for the European Market
}

\author{
Aline C. Galvao ${ }^{1}$, Carlo Nicoletto ${ }^{1, *(1)}$, Giampaolo Zanin ${ }^{1}\left(\mathbb{D}\right.$, Pablo F. Vargas ${ }^{2}$ and Paolo Sambo ${ }^{1}(\mathbb{D}$ \\ 1 Department of Agronomy, Food, Natural Resources, Animal and Environment-DAFNAE, University of \\ Padova, 35020 Legnaro, Italy; alinecarol.galvao@gmail.com (A.C.G.); paolo.zanin@unipd.it (G.Z.); \\ paolo.sambo@unipd.it (P.S.) \\ 2 Tropical Root and Starches Center (CERAT), Botucatu, São Paulo State University (UNESP), \\ São Paulo CEP 18.610-034, Brazil; pablo.vargas@unesp.br \\ * Correspondence: carlo.nicoletto@unipd.it; Tel.: +39-049-8272-826
}

Citation: Galvao, A.C.; Nicoletto, C.; Zanin, G.; Vargas, P.F.; Sambo, P.

Nutraceutical Content and Daily Value Contribution of Sweet Potato Accessions for the European Market. Horticulturae 2021, 7, 23.

https://doi.org/10.3390/

horticulturae7020023

Academic Editor: Lucia Guidi

Received: 31 December 2020

Accepted: 25 January 2021

Published: 30 January 2021

Publisher's Note: MDPI stays neutral with regard to jurisdictional claims in published maps and institutional affiliations.

Copyright: (c) 2021 by the authors. Licensee MDPI, Basel, Switzerland. This article is an open access article distributed under the terms and conditions of the Creative Commons Attribution (CC BY) license (https:/ / creativecommons.org/licenses/by/ $4.0 /)$.

\begin{abstract}
Sweet potatoes (SPs) are considered by the FAO as a primary crop for "traditional agriculture" in the tropics, but in Europe, its consumption is not widespread. However, consumer demand has grown exponentially over the past five years. This study has evaluated the quality and nutrient contents of storage roots of 29 SPs accessions to characterize their role in improving the human diet. Roots were analyzed for nutraceuticals, sugars, and minerals. Results underlined a considerable variability of nutrient content related to color among SPs accessions. The deep-orange-fleshed SPs showed a higher content of $\beta$-carotene compared to the light orange- and cream-fleshed ones; $100 \mathrm{~g}$ of edible product of HON86 can supply $32.3 \%$ of the daily value contribution of vitamin A, followed by the pale orange-fleshed BRA32 and BRA54. The total phenolic content of the purple ecotypes was about two to five times higher than the other genotypes. The calcium content was generally low, whereas, in many accessions, magnesium and phosphorus content reached $20 \%$, or higher of the contribution to the daily value. Such a high variability suggests different use of the different accessions according to their strengths, but might also be used for breeding to improve quality traits of the commercial varieties.
\end{abstract}

Keywords: Ipomoea batatas; nutrients requirement; $\beta$-carotene; vitamin A; minerals

\section{Introduction}

The sweet potato (Ipomoea batatas Lam.) is a tropical herbaceous plant cultivated worldwide that plays a significant role in human and animal nutrition, as well as being a source of starch for the food industry, only in tropical countries [1]. According to the FAO, in a tropical climate sweet potatoes (SPs) are considered a primary crop for "traditional agriculture" and is widely consumed, in particular in Asian and African countries [2]. The worldwide production of SP reached $91.8 \times 10^{7}$ tons in 2019 and is the seventh most cultivated food crop in the world [3].

The main edible parts of SP are its tuberous roots, where significant amounts of sugars [4], as well as vitamins, are stored. SPs are highly adaptive to sub-optimal climatic conditions, and thus they can be cultivated outside of tropical environments; its cultivation in Europe is not widespread, and its consumption is still unusual. However, consumer demand is growing exponentially, thanks to the rising interest in ethnic vegetables mediated by globalization and by nutraceutical research. For these reasons, both imports and consumption are rapidly growing, increasing by $100 \%$ over the last five years [5].

The phenological variability of SPs can influence the nutritional contents as reported by several authors [6,7]. The qualitative and nutritional characteristics of the sweet potato are many and concern different categories of nutrients including sugars, fibers, and vitamins, but the parameters that significantly increase their value towards the quality of the diet refer to the content of pigments and polyphenols. As is well known, despite being characterized 
by a general availability of food and good economic conditions, the European context presents important nutritional deficiencies especially in relation to micronutrients [8-10]. Indeed, red-orange-fleshed SPs rich in $\beta$-carotene can be considered as a smart food to fulfill the daily intake of carotenoids as reported by Islam et al. [11]. At the same time, the purple-fleshed varieties may increase the consumer's intake of valuable compounds such as anthocyanins, vitamin $\mathrm{C}$, and oligo-elements that can be used for counteracting food insecurity [11]. Anthocyanins, as well as carotenoids, can be accumulated and stored in plant cells and affect the color of plant tissues. Polyphenols such as carotenoids are involved as scavengers of reactive oxidative species (ROS) in cells. It is widely accepted that anthocyanins might be considered active compounds that reduce the risk of many inflammatory diseases (as observed in vitro) or might regulate diabetes and glycemic levels $[12,13]$. Although these compounds are present in all varieties of SPs, many studies reported that the highest amount of anthocyanins is contained in purple-fleshed varieties [14-16]. Therefore, orange- and purple-fleshed varieties might be appreciated by health-oriented consumers and hearten the consumption of SPs in Europe.

On the basis of the aforementioned premises, the purpose of the present study was to evaluate the content of nutritional and nutraceutical compounds in roots of 29 accessions of SPs deriving from different countries, Italy included, some of which were cultivated for the first time in Europe.

\section{Materials and Methods}

\subsection{Plant Material}

The field experiment was performed at the Experimental Farm of the University of Padova $\left(45^{\circ} 21^{\prime} \mathrm{N} ; 11^{\circ} 58^{\prime} \mathrm{E} ; 6 \mathrm{~m}\right.$ a.s.l.). The site has an annual average temperature of $12.3^{\circ} \mathrm{C}$ and an annual rainfall of $811 \mathrm{~mm}$. According to the USDA classification, the soil is a silty loam ( $11 \%$ clay, $65 \%$ silt, $24 \%$ sand) with a $\mathrm{pH}$ of 8.2 and $1.65 \%$ organic matter.

The propagation material of 29 accessions of SPs (Table 1), used in the experiment, was obtained from the genetic bank of Padova University in cooperation with the Tropical Root and Starches Center (São Paulo State University). On 22 January 2018, SP roots (100-150 g) were potted in a peat-based substrate (Potgrond H Klasmann-Deilmann GmbH, Geeste, Germany) amended with $20 \%(v / v)$ of perlite (Perlite Italiana, Corsico, Italy) and forced in a greenhouse at a temperature regime of $25 / 18^{\circ} \mathrm{C}$ day /night temperature, under natural light. On 6 June, the cuttings $(0.30-0.35 \mathrm{~m}$ in length) were collected and transplanted in an open field. Each accession was grown in plots of $7 \mathrm{~m}^{2}$ with four rows $0.8 \mathrm{~m}$ apart and with an in-row spacing of $0.29 \mathrm{~m}$ (30 plants per plot). Each plot was replicated three times and arranged in a randomized block design. The soil was fertilized with 80, 70, and $210 \mathrm{~kg}$ ha $^{-1}$ of $\mathrm{N}, \mathrm{P}_{2} \mathrm{O}_{5}$, and $\mathrm{K}_{2} \mathrm{O}$, respectively.

Cuttings were manually plugged at a depth of $0.10 \mathrm{~m}$ on raised beds and irrigated with about $100 \mathrm{~mL}$ of water per cutting.

During the growing period plants were irrigated three times, providing about $30 \mathrm{~mm}$ for each irrigation. SPs were then harvested at the commercial size, on 29th September. Harvested roots were cured and stored in the dark at room temperature $\left(17-20{ }^{\circ} \mathrm{C}\right.$ and $\mathrm{RH}$ of $65-70 \%)$ for six weeks before sampling. Sweet potato roots (250-300 $\mathrm{g}$ and at least $120 \mathrm{~mm}$ long) were randomly taken from each accession. Then stored roots were washed and brushed with tap water to remove any soil residues and dried with tissue paper. Afterward, roots were analyzed for dry matter content by weighing 30 roots per accession and replication before and after drying in a ventilated oven. The other qualitative assessments were performed on the same number of samples as shown below. 


\subsection{Chemical Reagents}

Acetic acid (glacial) and anhydrous sodium carbonate were purchased from Riedel-de Haën (Hanover, Germany). Gallic acid monohydrate was obtained from Fluka (SigmaAldrich, Milan, Italy), methanol from VWR Prolabo (Fontenay-sous-Bois, France), and FolinCiocalteu's (FC) reagent from Labochimica (Padova, Italy). Chlorogenic acid hemihydrates, maltose, D-(+)-glucose, and D-(-)-fructose were purchased from Aldrich Chemical Company (Sigma-Aldrich); caffeic acid, p-coumaric acid, and ferulic acid from Sigma and methanol from Carlo Erba (Milan, Italy). Deionized water (18 M $\Omega$ ) was prepared using an ultrapure water purification system (Arium ${ }^{\circledR}$ pro; Sartorius, Muggiò, Italy). All reagents and standards were of analytical and high-performance liquid chromatography (HPLC) grade.

Table 1. List of the sweet potato genetic materials and their main morphological traits.

\begin{tabular}{|c|c|c|c|c|}
\hline $\begin{array}{l}\text { Genetic } \\
\text { Material }\end{array}$ & $\begin{array}{c}\text { Country of } \\
\text { Origin }\end{array}$ & Flesh Color & Skin Color & Roots Shape \\
\hline Bra1 & Brazil & Purple & Dark purple & Elliptic \\
\hline Bra11 & Brazil & Cream & Pink & Round elliptic \\
\hline Bra13 & Brazil & White & Cream & Elliptic \\
\hline Bra25 & Brazil & Purple & Cream & Long oblong \\
\hline Bra30 & Brazil & White & Pink & Long irregular \\
\hline Bra32 & Brazil & Pale orange & Pink & Oblong \\
\hline Bra33 & Brazil & Purple & Cream & Oblong \\
\hline Bra51 & Brazil & White & Cream & Long elliptic \\
\hline Bra53 & Brazil & Purple & White & Oblong \\
\hline Bra54 & Brazil & Intermediate orange & Yellow & Elliptic \\
\hline Bra66 & Brazil & White & White & Long irregular \\
\hline Bra78 & Brazil & Cream & Pink & Long irregular \\
\hline Bra79 & Brazil & Purple & Pink & Obovate \\
\hline Bra 80 & Brazil & Purple & Dark purple & Obovate \\
\hline Hon86 & Honduras & Deep orange & Purple-red & Round elliptic \\
\hline IT41 & Italy & Cream & Cream & Long irregular \\
\hline IT42 & Italy & Cream & Pink & Round \\
\hline IT43 & Italy & Pale yellow & Pink & Obovate \\
\hline IT44 & Italy & White & Cream & Elliptic \\
\hline IT46 & Italy & Cream & Pink & Obovate \\
\hline IT47 & Italy & Cream & Cream & Ovate \\
\hline IT48 & Italy & Cream & Cream & Round elliptic \\
\hline IT49 & Italy & Pale yellow & Pink & Round elliptic \\
\hline IT81 & Italy & Cream & Cream & Obovate \\
\hline IT82 & Italy & Cream & Cream & Round elliptic \\
\hline IT83 & Italy & Cream & Cream & Obovate \\
\hline IT84 & Italy & Cream & Cream & Long irregular \\
\hline USA85 & USA & Pale yellow & Cream & Round elliptic \\
\hline USA45 & USA & Purple & Dark purple & Long oblong \\
\hline
\end{tabular}

\subsection{Extraction of Phenols for Analysis}

Freeze-dried (Scanvac, Coolsafe model, LaboGene, Denmark) samples $(0.5 \mathrm{~g})$ were extracted in methanol $(20 \mathrm{~mL})$ with an Ultra Turrax T25 (IKA-Labortechnik, Staufen, Germany) at 13,500 rpm until a uniform consistency was achieved. Samples were filtered (589 filter paper; Whatman, Germany) and appropriate aliquots of extracts were assayed by FC reagent for total phenolic (TP) content and by the ferric reducing antioxidant power (FRAP method) for antioxidant activity. For HPLC analyses, extracts were further filtered by cellulose acetate syringe filters $(0.45 \mu \mathrm{m}$ porosity). 


\subsection{Determination of TP Content by the FC Assay}

The content of TP was determined by the FC assay with gallic acid as a calibration standard, using a UV-1800 spectrophotometer (Shimadzu, Columbia, MD, USA). The FC assay was carried out on $200 \mu \mathrm{L}$ of SP extract in a $10 \mathrm{~mL}$ test tube, followed by the addition of FC reagent $(1000 \mu \mathrm{mL})$. The mixture was vortexed for $20-30 \mathrm{~s}$ and $800 \mu \mathrm{L}$ of filtered $20 \%$ sodium carbonate solution was added within 1-8 min after the FC reagent addition. The mixture was then vortexed again for 20-30 s (time 0). After two hours at room temperature, the absorbance of the colored reaction product was measured at $765 \mathrm{~nm}$ by a Shimadzu UV-1800 spectrophotometer (Columbia, MD, USA). The TP content in extracts was calculated from a standard calibration curve obtained with different concentrations of gallic acid, ranging from 0 to $600 \mu \mathrm{g} \mathrm{mL} \mathrm{m}^{-1}$ (correlation coefficient: $\mathrm{r}^{2}=0.9993$ ). The results are expressed as $\mathrm{mg}$ gallic acid equivalent (GAE) $\mathrm{kg}^{-1}$ dry weight.

\subsection{Determination of Total Antioxidant Activity (TAA) by FRAP}

The FRAP reagent was freshly prepared and consisted of $1 \mathrm{mmol} \mathrm{L}^{-1}$ of 2,4,6-tripyridyl2-triazine and $2 \mathrm{mmol} \mathrm{L}^{-1}$ of ferric chloride in a $0.25 \mathrm{~mol} \mathrm{~L}^{-1}$ sodium acetate solution (pH 3.6). A methanol extract aliquot $(100 \mu \mathrm{L})$ was added to the FRAP reagent $(1900 \mu \mathrm{L})$ and accurately mixed. After four min at room temperature, the absorbance was determined at $593 \mathrm{~nm}$ by a Shimadzu UV-1800 spectrophotometer. The calibration was performed with a standard curve $\left(0-1200 \mu \mathrm{g} \mathrm{mL} \mathrm{m}^{-1} \mathrm{Fe}^{2+}\right)$ (correlation coefficient: $\left.\mathrm{r}^{2}=0.9985\right)$, obtained by the addition of freshly prepared ammonium ferrous sulfate. FRAP values were calculated as $\mu \mathrm{g} \mathrm{mL} \mathrm{L}^{-1} \mathrm{Fe}^{2+}$ (ferric reducing power) from three determinations and reported as $\mathrm{mg} \mathrm{kg}^{-1}$ of $\mathrm{Fe}^{2+}$ (ferrous ion equivalent) on dry matter.

\subsection{Extraction and Determination of Ascorbic Acid}

Ascorbic acid was determined by a standard method (ISO 6557/2, 1984). SPs freezedried samples ( $1 \mathrm{~g}$ ) were homogenized until a uniform consistency was achieved with an Ultra Turrax in $20 \mathrm{~mL}$ of meta-phosphoric acid and acetic acid solution. As a colorant reagent, a solution of 2,6-dichlorophenolindophenol was employed. Samples, after adding xylene and $3 \mathrm{~min}$ of centrifugation at $4000 \mathrm{rpm}$, were measured with a Shimadzu UV1800 spectrophotometer at a wavelength of $500 \mathrm{~nm}$.

\subsection{Quantitative Determination of Sugars by HPLC}

SPs root freeze-dried samples $(0.2 \mathrm{~g})$ were homogenized in demineralized water $(20 \mathrm{~mL})$ with an Ultra Turrax T25 at 13,500 rpm until a uniform consistency was achieved. Samples were filtered through filter paper (589; Schleicher), and the extracts were further filtered through cellulose acetate syringe filters $(0.45 \mu \mathrm{m})$ and analyzed by HPLC. The liquid chromatography apparatus utilized in this analysis was a Jasco X.LC system consisting of a model PU-2080 pump, a model RI-2031 refractive index detector, a model AS-2055 autosampler, and a model CO-2060 column. ChromNAV Chromatography Data System software was used for the analysis of the results. The separation of sugars was achieved on a Hyper-Rez XP Carbohydrate $\mathrm{Pb}^{++}$analytical column $(7.7 \times 300 \mathrm{~mm}$; Thermo Scientific, Waltham, MA, USA), operating at $80{ }^{\circ} \mathrm{C}$. Isocratic elution was effected using water at a flow rate of $0.6 \mathrm{~mL} \mathrm{~min}^{-1}$. D-(+)-glucose, D-(-)-fructose, and maltose were quantified by a calibration method. All standards utilized in the experiments were accurately weighed, dissolved in water and the calibration curves were generated with concentrations ranging from 100 to $1000 \mathrm{mg} \mathrm{L}^{-1}$ of standards.

\subsection{Quantitative Determination of Ions by IC and Organic Nitrogen}

For the estimation of anions and cations, each freeze-dried sample $(0.2 \mathrm{~g})$ was extracted in water $(50 \mathrm{~mL})$ and shaken at $150 \mathrm{rpm}$ for $20 \mathrm{~min}$. Samples were filtered through filter paper (589 Schleicher), and the extracts were further filtered through cellulose acetate syringe filters $(0.20 \mu \mathrm{m})$ before analysis by ion chromatography (IC). The IC was performed using an ICS-900 Ion Chromatography system (Dionex Corporation) equipped with a 
dual-piston pump, a model AS-DV autosampler, an isocratic column at room temperature, a DS5 conductivity detector, and an AMMS 300 suppressor $(4 \mathrm{~mm})$ for anions and CMMS 300 suppressor $(4 \mathrm{~mm}$ ) for cations. Chromeleon 6.5 Chromatography Management Software was used for system control and data processing. A Dionex Ion-Pac AS23 analytical column $(4 \mathrm{~mm} \times 250 \mathrm{~mm})$ and a guard column $(4 \mathrm{~mm} \times 50 \mathrm{~mm})$ were used for anion separations, whereas a Dionex IonPac CS12A analytical column $(4 \mathrm{~mm} \times 250 \mathrm{~mm})$ and a guard column $(4 \mathrm{~mm} \times 50 \mathrm{~mm}$ ) were used for cation separations. The eluent consisted of $4.5 \mathrm{mM}$ sodium carbonate and $0.8 \mathrm{mM}$ sodium bicarbonate at a flow rate of $1 \mathrm{~mL} \mathrm{~min}^{-1}$ for anions and of $20 \mathrm{mM}$ methanesulphonic acid for cations at the same flow rate. Anions and cations were quantified following a calibration method. Dionex solutions containing seven anions at different concentrations and five cations were taken as standards, and the calibration curves were generated with concentrations ranging from $0.4 \mathrm{mg} \mathrm{L}^{-1}$ to $20 \mathrm{mg} \mathrm{L}^{-1}$ and from $0.5 \mathrm{mg} \mathrm{L}^{-1}$ to $50 \mathrm{mg} \mathrm{L}^{-1}$ of standards, respectively.

\section{9. $\beta$-Carotene Quantification}

Beta-carotene was measured according to the procedure described by $[17,18]$ with some modifications. For HPLC determination, $0.2 \mathrm{~g}$ of freeze-dried material for each cultivar sample was used and carotenoids were extracted with $20 \mathrm{~mL}$ of tetrahydrofuran (THF). The mixture was mechanically stirred for $30 \mathrm{~s}$ and the extract was filtrated with syringe filters in regenerated cellulose $0.45 \mu \mathrm{m}$. The samples were injected into an HPLC model Shimadzu liquid chromatography system (model SCL 10AT VP) equipped with a high-pressure pump (model LC-10AT VP), automatic loop injector $(50 \mu \mathrm{L}$; model SIL10AF). Column: Tracer Extrasil ODS2 $(250 \times 45 \mathrm{~mm}, 5 \mu \mathrm{m})$ using the mobile phase methanol:THF:water $(67: 27: 6, v / v / v)$. The flow-rate of the mobile phase was $1 \mathrm{~mL} \mathrm{~min}^{-1}$ and the absorbance was measured at $470 \mathrm{~nm}$.

\subsection{Starch Determination}

The starch content was determined using the modified AOAC Official Method 996.11 Starch (total) in cereal products and AOAC Official Method 979.10-Starch in Cereals reported by Bulletin 339-2000.

\subsection{Sweet Potato Contribution to Daily Value (SP Contribution to Daily Value)}

The contributions of SPs to the daily recommended intake (daily value, DV) for Vitamin A, Vitamin C, potassium, phosphorus, calcium, and magnesium were calculated by assuming an intake of $100 \mathrm{~g}$ fresh product per day. The dietary reference values were set according to the European Food Safety Authority (https://www.efsa.europa. $\mathrm{eu} / \mathrm{en} /$ interactive-pages/drvs). Values of retinol, vitamin C, potassium, phosphorus, calcium, and magnesium were calculated for adults ( $>18$ years) and children/adolescents (1-17 years). For each value, the corresponding percentage to DV was calculated by the following equation:

DV $(\%)=$ nutrient content in $100 \mathrm{~g}(\mathrm{FW})$ 100/average daily requirement.

\subsection{Statistical Analysis}

The complete set of data for each variety was analyzed by the PCA procedure using the software Statgraphics Centurion 18.1.06 (Statgraphics Technologies, Inc., The Plains, VA, USA). All qualitative trait data were processed by ANOVA using the software CoStat 6.400 (CoHort Software, CA, USA). The comparison has been realized among all the sweet potato genotypes using a one-way randomized block analysis type. In the case of significant differences, mean values were separated by Tukey HSD test. 


\section{Results}

The highest percentages of dry matter content in the root $(>40 \%)$ were found in the accessions Bra66, Bra78, Bra80, and IT48, and the lowest $(<31 \%)$ in Bra30, Bra1, and IT49 (Table 2).

Table 2. Main qualitative composition of the tested sweet potato accessions.

\begin{tabular}{|c|c|c|c|c|c|}
\hline $\begin{array}{c}\text { Genetic } \\
\text { Materials }\end{array}$ & $\begin{array}{c}\text { Dry Matter } \\
(\%)\end{array}$ & $\begin{array}{l}\text { Starch } \\
(\% \text { dw })\end{array}$ & $\begin{array}{l}\text { Sucrose } \\
\mathrm{g} / \mathrm{kg} \mathrm{dw}\end{array}$ & $\begin{array}{l}\text { Glucose } \\
\text { g/kg dw }\end{array}$ & $\begin{array}{l}\text { Fructose } \\
\text { g/kg dw }\end{array}$ \\
\hline Bra1 & $35.9^{b}$ & $69.5^{c}$ & 76.0 hij & 21.7 def & $16.2 \mathrm{efg}$ \\
\hline Bra11 & $34.7^{\mathrm{b}}$ & $72.4^{\mathrm{b}}$ & $88.8^{\text {ghi }}$ & $19.8^{\text {efg }}$ & $14.9 \mathrm{efg}$ \\
\hline Bra13 & $32.3^{b c}$ & $64.6^{c}$ & $106^{\text {efg }}$ & $8.58^{\mathrm{ijk}}$ & $6.09 \mathrm{~g}$ \\
\hline Bra25 & $35.9^{b}$ & $71.6^{b}$ & $55.7^{\mathrm{jkl}}$ & $32.6^{\mathrm{bcd}}$ & $32.5^{\mathrm{bcd}}$ \\
\hline Bra30 & $30.7^{c}$ & $69.5^{c}$ & $68.2^{\mathrm{ijk}}$ & $46.2^{\mathrm{a}}$ & $34.1 \mathrm{abcd}$ \\
\hline Bra32 & $32^{b c}$ & $71.8^{\mathrm{b}}$ & $138^{a b c}$ & $16.7^{\mathrm{efg}}$ & $14.4^{\mathrm{efg}}$ \\
\hline Bra33 & $35.9^{b}$ & $82.5^{\mathrm{ab}}$ & $37.5^{\mathrm{kl}}$ & $27.1^{\text {cde }}$ & $30.2^{\mathrm{cd}}$ \\
\hline Bra51 & $29.5^{c}$ & $69.6^{c}$ & $114^{\text {cde }}$ & $46.6^{\mathrm{a}}$ & $43.5^{\mathrm{ab}}$ \\
\hline Bra53 & $34.3^{b}$ & $70.5^{b c}$ & $117^{\text {cde }}$ & $22.1^{\text {def }}$ & 23.2 def \\
\hline Bra54 & $36.6^{\mathrm{b}}$ & $77.9^{b}$ & $134^{b c d}$ & 13.9 ghi & $11.2^{\mathrm{fg}}$ \\
\hline Bra66 & $41.5^{\mathrm{a}}$ & $63.6^{c}$ & $150^{\mathrm{a}}$ & $6.72^{\mathrm{jk}}$ & $7.16^{\mathrm{g}}$ \\
\hline Bra78 & $41.8^{\mathrm{a}}$ & $69.8^{c}$ & $97.8^{\mathrm{fgh}}$ & 19.1 efg & 15.1 efg \\
\hline Bra79 & $37.2^{b}$ & $71.2^{b}$ & $110^{\text {cde }}$ & 13.7 ghi & $12.0 \mathrm{fg}$ \\
\hline Bra80 & $43.1^{\mathrm{a}}$ & $74.4^{b}$ & $93.2^{\mathrm{fgh}}$ & $10.5 \mathrm{ghi}$ & $9.50^{\mathrm{g}}$ \\
\hline Hon86 & $35.9^{b}$ & $52.3^{d}$ & $95.5^{\mathrm{fgh}}$ & $43.2^{\mathrm{ab}}$ & $46.2^{\mathrm{a}}$ \\
\hline IT41 & $36.6^{b}$ & $82.9^{a b}$ & $103^{\text {efg }}$ & 9.30 hij & $7.63^{g}$ \\
\hline IT42 & $34.3^{b}$ & $72.6^{b}$ & 74.0 hij & $38.1^{a b c}$ & $36.6^{\mathrm{abc}}$ \\
\hline IT43 & $33.2 \mathrm{bc}$ & $73.4^{b}$ & $144^{\mathrm{ab}}$ & $12.3 \mathrm{ghi}$ & $10.4^{\mathrm{g}}$ \\
\hline IT44 & $36.8^{\mathrm{b}}$ & $78.9^{b}$ & 109 def & $4.94^{\mathrm{k}}$ & $3.87^{g}$ \\
\hline IT46 & $34.2^{b}$ & $74.7^{b}$ & $76.3^{\text {hij }}$ & $15.5^{\mathrm{efg}}$ & $15.5^{\mathrm{efg}}$ \\
\hline IT47 & $35.7^{b}$ & $91.3^{\mathrm{a}}$ & 95.9 fgh & $7.38^{\mathrm{ijk}}$ & $5.16^{\mathrm{g}}$ \\
\hline IT48 & $40.4^{\mathrm{a}}$ & $89.2^{a}$ & $93.2^{\mathrm{fgh}}$ & $7.90^{\mathrm{ijk}}$ & $5.52 \mathrm{~g}$ \\
\hline IT49 & $30.4^{c}$ & $79.5^{b}$ & $92.2 \mathrm{ghi}$ & $36.8^{a b c}$ & $24.5^{\text {cde }}$ \\
\hline IT81 & $36.2^{b}$ & $72.2^{b}$ & $125^{b c d}$ & $5.24^{\mathrm{k}}$ & $3.83^{\mathrm{g}}$ \\
\hline IT82 & $33.9 \mathrm{bc}$ & $73.4^{b}$ & $111^{\text {cde }}$ & 10.9 ghi & $8.98^{g}$ \\
\hline IT83 & $39.5^{a b}$ & $76.8^{b}$ & $107^{\text {def }}$ & $7.87^{\mathrm{ijk}}$ & $5.97 \mathrm{~g}$ \\
\hline IT84 & $39.6^{\mathrm{ab}}$ & $69.9^{c}$ & $94.7 \mathrm{fgh}$ & $7.00 \mathrm{jk}$ & $4.43^{\mathrm{g}}$ \\
\hline USA45 & $35.9^{b}$ & $81.4^{\mathrm{ab}}$ & $36.4^{1}$ & $37.0^{\mathrm{abc}}$ & $35.2^{\mathrm{abcd}}$ \\
\hline USA85 & $35.9^{b}$ & $60.1^{\mathrm{cd}}$ & $69.6^{\mathrm{ijk}}$ & $26.4^{\text {cde }}$ & $31.5^{\mathrm{bcd}}$ \\
\hline
\end{tabular}

Within each parameter, values without common letters significantly differed at $p<0.05$ according to Tukey's HSD test.

The percentage of starch in SP accessions ranged from $52.3 \%$ of Hon86 to $91.3 \%$ of IT47. Dividing the accessions according to starch content $(<70 \%, 70-80 \%$, and $>80 \%)$ into three groups 9 out of the 29 accessions showed low starch content, 15 accessions the intermediate content, and 5 accessions the high content. Considering the origin of the accessions, Brazilian accessions had lower values $(71.3 \%$, on average) than the Italian ones (77.5\%, on average) (Table 2 ).

Results on the raw product showed that the sucrose content of Bra66 $\left(150 \mathrm{~g} \mathrm{~kg}^{-1} \mathrm{dw}\right)$ was four-times higher than USA45 $\left(36.4 \mathrm{~g} \mathrm{~kg}^{-1} \mathrm{dw}\right)$ (Table 2). Glucose content in storage roots varied from 4.94 to $46.6 \mathrm{~g} \mathrm{~kg}^{-1} \mathrm{dw}$; Bra51, Bra30, and Hon86 had the highest amount of glucose, with values 10-times higher than the lower one (IT44). Hon86 showed the higher values of fructose $\left(46.2 \mathrm{~g} \mathrm{~kg}^{-1} \mathrm{dw}\right)$, statistically similar to those of Bra51 and IT42 (43.5 and $36.6 \mathrm{~g} \mathrm{~kg}^{-1} \mathrm{dw}$, respectively). Accessions with the lowest content of fructose were found for cream-fleshed SP and white-fleshed SP, such as IT81, IT44, and IT84, with values ranging between 3.83 and $4.43 \mathrm{~g} \mathrm{~kg}^{-1} \mathrm{dw}$. 
Figure 1 shows the TP contents and TAA of raw SP roots on a dry weight basis. Content of TP ranged between 870 and $6440 \mathrm{mg} \mathrm{GAE} \mathrm{kg}^{-1} \mathrm{dw}$. In the purple ecotypes, the TP content was about two to five times higher than other genotypes. The TAA of roots decreased from purple-fleshed $>$ white-fleshed $>$ orange-fleshed $>$ cream-fleshed SP accessions. The higher antioxidant activity was found in purple-fleshed accessions USA45, Bra1, Bra25, and Bra80, with 6700, 4654, 3562, and $2561 \mathrm{mg} \mathrm{Fe}^{2+} \mathrm{E} \mathrm{kg}^{-1} \mathrm{dw}$, respectively.

A

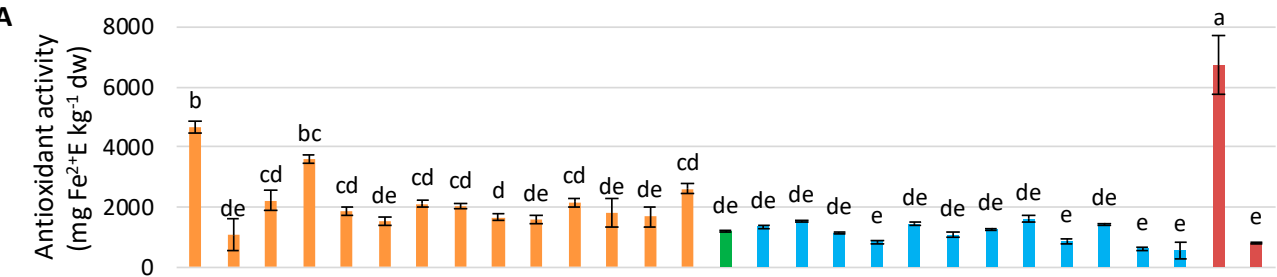

B

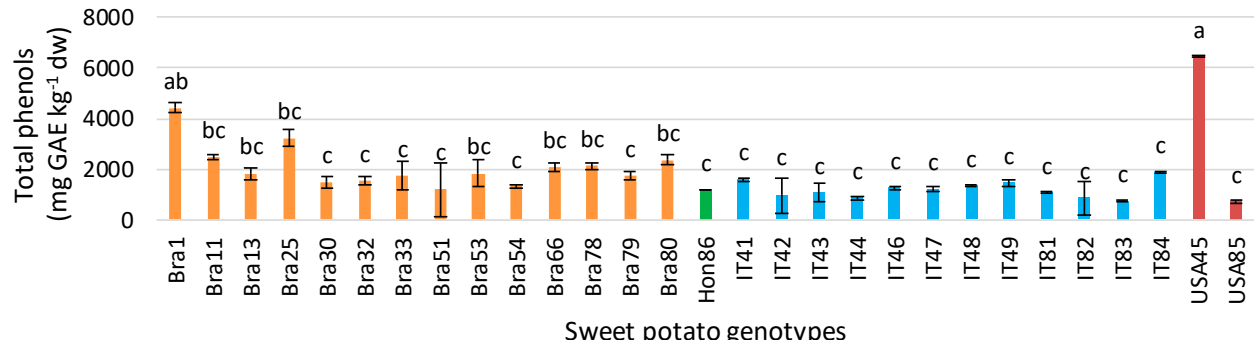

Figure 1. Total phenols content and total antioxidant activity of sweet potato genotypes. Histogram values without common letters significantly differed at $p<0.05$ according to Tukey's HSD test.

As for the content in mineral elements and vitamins $C$ and $A$, the values determined in the different accessions have been transformed into the percentage of contribution that a portion of $100 \mathrm{~g}$ can provide to the consumer. The reference values used for this processing (SP\% contribution to DV) refer to the standards of the European Food Safety Agency (EFSA) and were calculated for both the adult (Table 3) and children (Table 4) consumers.

In Table 3, the higher levels of phosphorus were found in USA45, IT43, IT44, Bra53, and Bra54. One hundred grams of raw SP may provide up to $12.6 \%$ contribution to the DV of potassium; the lowest values belong to the colored accessions (purple-, pale-yellow, or orange-fleshed PS), whereas the accessions with pale colors had the highest contribution to the DV. The same pattern was observed for magnesium, and the accessions with the highest contribution to the DV were IT84, IT83, Bra78, and IT44, (39.5\%, 31.9\%, 28.1\%, and $28.0 \%$, respectively). The contribution of the SPs to the DV of calcium ranged between 4.99\% and 10.9\%. IT84, Bra80, Bra54, Bra79, Hon86, and USA85 accessions had the highest content of calcium. The contribution of the SPs to the DV of vitamin C showed a high variation among the accessions with values ranging from $26.2 \%$ to $197 \%$; the cream-fleshed SPs and purple-fleshed SPs were found to have the highest supply of vitamin C.

As for the contribution to the DV of vitamin A, some accessions did not show relevant values. However, Hon86 had the highest values (32.3\%). The white-fleshed SPs showed really low values of vitamin $\mathrm{A}$, and in some accessions, the contents were lower than those assessable by the method. The accessions with cream- or light-orange-flesh had the intermediate levels and, in any case, lower than 5\% (Table 3). In Table 4, the values of the nutritional parameters have presented the same trends described for the adult consumer, obviously these results are conditioned by a different daily requirement that distinguishes the consumer under the age of 17. 
Table 3. Percentage of the contribution to the daily value of minerals and vitamins based on $100 \mathrm{~g}$ fresh sweet potato consumption per day for the different accessions according to adults' needs (European Food Safety Agency standards).

\begin{tabular}{|c|c|c|c|c|c|c|c|c|}
\hline $\begin{array}{l}\text { Genetic } \\
\text { Material }\end{array}$ & $\mathbf{P}$ & $\mathbf{K}$ & $\mathrm{Na}$ & $\mathrm{Cl}$ & $\mathrm{Mg}$ & $\mathrm{Ca}$ & Vit C & Vit A \\
\hline Bra1 & 6.78 ef & $5.44^{\mathrm{n}}$ & $5.28^{\mathrm{a}}$ & $3.41^{\mathrm{a}}$ & $15.2^{\mathrm{gh}}$ & $7.20^{b c}$ & $186^{a}$ & n.d. \\
\hline Bra11 & $8.14^{\mathrm{ab}}$ & $10.4^{\text {ef }}$ & $2.38^{h i}$ & $1.54^{\mathrm{ij}}$ & $14.4^{\mathrm{gh}}$ & $6.45^{\mathrm{cd}}$ & $119^{a b}$ & n.d. \\
\hline Bra13 & $\begin{array}{l}6.56 \\
\text { fgh }\end{array}$ & $6.77^{\mathrm{m}}$ & $4.93^{\mathrm{ab}}$ & $3.18^{a b}$ & $24.4^{\text {de }}$ & $6.74^{\mathrm{cd}}$ & $105^{b}$ & n.d. \\
\hline Bra25 & $6.10^{\text {hi }}$ & $7.25^{\mathrm{kl}}$ & $3.89 \mathrm{~cd}$ & $2.51^{\mathrm{cd}}$ & $16.2^{\mathrm{gh}}$ & $7.94^{b c}$ & $119^{a b}$ & n.d. \\
\hline Bra30 & $3.46^{\circ}$ & $5.94^{\mathrm{n}}$ & 3.51 ef & $2.26^{\mathrm{ef}}$ & $18.6^{\text {ef }}$ & $5.97 \mathrm{de}$ & n.d. & $0.49^{\mathrm{c}}$ \\
\hline Bra32 & $4.67 \mathrm{~lm}$ & $7.40 \mathrm{kl}$ & $5.27^{\mathrm{a}}$ & $3.40^{\mathrm{a}}$ & $15.0^{\mathrm{gh}}$ & $7.74^{b c}$ & $167^{\mathrm{a}}$ & $4.55^{b}$ \\
\hline Bra33 & $7.25^{\mathrm{cd}}$ & $6.99 \mathrm{~lm}$ & 3.58 de & $2.31^{\text {de }}$ & $15.0^{\mathrm{gh}}$ & 5.97 de & $154^{\mathrm{ab}}$ & n.d. \\
\hline Bra51 & $5.66^{\mathrm{ij}}$ & 7.93 ij & 3.77 de & $2.43^{\mathrm{de}}$ & $17.3^{\mathrm{fg}}$ & 5.64 de & $126^{a b}$ & $0.18^{c}$ \\
\hline Bra53 & $8.68^{a b}$ & 8.78 gh & $5.14^{\mathrm{a}}$ & $3.31^{\mathrm{a}}$ & $17.0 \mathrm{fg}$ & $9.62 \mathrm{bc}$ & n.d. & n.d. \\
\hline Bra54 & $8.49^{a b}$ & $6.98 \mathrm{~lm}$ & 3.47 ef & 2.24 ef & $27.4^{\mathrm{cd}}$ & $10.1^{\mathrm{ab}}$ & $93.0 \mathrm{bc}$ & $3.67^{b}$ \\
\hline Bra66 & $7.64^{b c}$ & $12.6^{b c}$ & $2.65^{\mathrm{hi}}$ & $1.71^{\mathrm{ij}}$ & $26.9^{\mathrm{cd}}$ & $7.84^{b c}$ & $106^{b}$ & $0.17^{c}$ \\
\hline Bra78 & $8.23^{\mathrm{ab}}$ & $8.18^{\text {hi }}$ & $4.77^{\mathrm{ab}}$ & $3.08^{a b}$ & $28.1^{b c}$ & $7.96^{b c}$ & $58.3^{d}$ & n.d. \\
\hline Bra79 & $7.62^{b c}$ & $12.9^{b}$ & $0.88^{1}$ & $0.57^{1}$ & $19.6^{\text {ef }}$ & $9.70 \mathrm{bc}$ & n.d. & n.d. \\
\hline Bra80 & $5.91 \mathrm{ij}$ & $7.28^{\mathrm{kl}}$ & $2.93 \mathrm{gh}$ & $1.89 \mathrm{gh}$ & $26.9^{\mathrm{cd}}$ & $10.9^{\mathrm{a}}$ & $190^{\mathrm{a}}$ & n.d. \\
\hline Hon86 & $7.24^{\mathrm{cd}}$ & $12.2^{\mathrm{c}}$ & $1.77^{\mathrm{k}}$ & $1.14^{\mathrm{k}}$ & $22.5^{\text {de }}$ & $8.61^{b c}$ & $98.7^{b c}$ & $32.3^{a}$ \\
\hline IT41 & $7.11^{\mathrm{cd}}$ & $11.1^{\mathrm{d}}$ & $2.20^{\mathrm{ij}}$ & $1.42^{\mathrm{jk}}$ & $22.5^{\text {de }}$ & $6.58^{\mathrm{cd}}$ & $85.8^{c}$ & n.d. \\
\hline IT42 & $6.84^{\text {de }}$ & $11.0^{\text {de }}$ & $4.47^{b c}$ & $2.88^{b c}$ & $11.1^{\mathrm{h}}$ & 5.97 de & $197^{\mathrm{a}}$ & $0.75^{c}$ \\
\hline IT43 & $8.78^{a b}$ & $14.3^{\mathrm{a}}$ & $0.86^{1}$ & $0.55^{1}$ & $16.4^{\mathrm{gh}}$ & $6.83^{\mathrm{cd}}$ & n.d. & n.d. \\
\hline IT44 & $8.37^{\mathrm{ab}}$ & $8.47^{\text {hi }}$ & $2.74^{\mathrm{gh}}$ & $1.77^{\mathrm{hi}}$ & $28.0^{b c}$ & $7.45^{b c}$ & $69.2^{\mathrm{d}}$ & n.d. \\
\hline IT46 & $5.84^{\mathrm{ij}}$ & $9.97^{\mathrm{f}}$ & $5.10^{\mathrm{a}}$ & $3.29^{a}$ & 20.0 ef & 5.93 de & n.d. & n.d. \\
\hline IT47 & $4.83 \mathrm{~lm}$ & $6.99 \mathrm{~lm}$ & $2.54 \mathrm{hi}$ & $1.64^{\mathrm{ij}}$ & 21.7 de & $6.52 \mathrm{~cd}$ & n.d. & n.d. \\
\hline IT48 & $5.11^{\mathrm{kl}}$ & $7.83^{\mathrm{ij}}$ & $2.77 \mathrm{gh}$ & 1.79 hi & 23.1 de & $7.53^{b c}$ & $92.2^{b c}$ & n.d. \\
\hline IT49 & $3.87^{\text {no }}$ & $6.81^{\mathrm{m}}$ & $4.03^{\mathrm{cd}}$ & $2.60^{\mathrm{cd}}$ & 20.0 ef & $4.99^{\mathrm{e}}$ & $46.9^{\mathrm{d}}$ & $1.11^{\mathrm{c}}$ \\
\hline IT81 & $5.18^{\mathrm{jk}}$ & $12.6^{b c}$ & $2.18^{\mathrm{ij}}$ & $1.40^{\mathrm{jk}}$ & $27.9^{b c}$ & $7.33^{81}$ & $102^{b}$ & n.d. \\
\hline IT82 & $\begin{array}{l}6.69 \\
\text { fgh }\end{array}$ & $12.5^{b c}$ & $2.09 \mathrm{jk}$ & $1.35^{\mathrm{jk}}$ & $22.3^{\mathrm{de}}$ & $6.41^{\mathrm{cd}}$ & $103^{b}$ & n.d. \\
\hline IT83 & 6.90 de & $9.89^{\mathrm{f}}$ & $3.35 \mathrm{fg}$ & $2.16^{\mathrm{fg}}$ & $31.9^{\mathrm{ab}}$ & $8.45^{b c}$ & $72.4^{\mathrm{d}}$ & n.d. \\
\hline IT84 & $\begin{array}{c}4.38 \\
\mathrm{mn}\end{array}$ & $5.57^{n}$ & $3.30 \mathrm{fg}$ & $2.13^{\mathrm{fg}}$ & $39.5^{\mathrm{a}}$ & $9.31^{b c}$ & $129 \mathrm{ab}$ & n.d. \\
\hline US45 & $8.99^{a}$ & $7.56^{\mathrm{jk}}$ & $5.02^{\mathrm{ab}}$ & $3.24^{\mathrm{ab}}$ & $24.8^{\text {de }}$ & $6.83^{\mathrm{cd}}$ & $26.2^{\mathrm{e}}$ & n.d. \\
\hline US85 & $5.12^{\mathrm{kl}}$ & $9.19^{\mathrm{g}}$ & $2.66^{\mathrm{hi}}$ & $1.71^{\mathrm{ij}}$ & $20.7^{\text {ef }}$ & $8.55^{b c}$ & $63.5^{\mathrm{d}}$ & n.d. \\
\hline
\end{tabular}

Within each parameter, values without common letters significantly differed at $p<0.05$ according to Tukey's HSD test. . $d=$ not detected.

It is interesting to underline that some genotypes can satisfy significant amounts of nutrients such as USA45 for phosphorus (11.2\%), IT43 for potassium $(27.9 \%)$, IT84 for magnesium (46\%), and BRA80 for calcium (13\%). Most of the accessions considered $(>75 \%)$ can completely satisfy the need for vitamin C, additionally, HON86 contributes more than $50 \%$ of the daily requirement of retinol (vitamin A). The analysis of the PCA and the vector components summarize in a clear way the behavior of the SP accessions in relation to the nutritional potential of a $100 \mathrm{~g}$ ration for an adult (Figure 2) and a child (Figure 3). The data of the two categories of consumers are quite similar. However, in both, it is possible to identify three groups of accession able to better satisfy nutritional needs. Particularly, group 1 includes accessions able to supply a significant amount of phosphorus, potassium, and chlorine; for group 2 calcium and magnesium are the most present elements; finally, the third group is characterized by a higher concentration of sodium and vitamin C. Some genotypes have intermediate characteristics, such as IT47 and IT44, which are placed in the center of the figure, and Bra11 which is positioned between groups 1 and 3 . 
Table 4. Percentage of the contribution to the daily value of minerals and vitamins based on $100 \mathrm{~g}$ fresh sweet potato consumption per day for the different accessions according to children needs (European Food Safety Agency standards).

\begin{tabular}{|c|c|c|c|c|c|c|c|c|}
\hline $\begin{array}{l}\text { Genetic } \\
\text { Material }\end{array}$ & $\mathbf{P}$ & $\mathbf{K}$ & $\mathrm{Na}$ & $\mathrm{Cl}$ & $\mathrm{Mg}$ & $\mathrm{Ca}$ & Vit C & Vit A \\
\hline Bra1 & 8.47 ef & $10.6^{n}$ & $6.21^{\mathrm{a}}$ & $2.57^{b c}$ & $17.7^{\mathrm{fg}}$ & $8.55^{\mathrm{ab}}$ & $419^{a}$ & n.d. \\
\hline Bra11 & $10.2^{b c}$ & $20.1^{\text {ef }}$ & $2.80^{\mathrm{hi}}$ & $2.58^{b c}$ & $16.8^{\mathrm{gh}}$ & $7.65^{b c}$ & $268^{b}$ & n.d. \\
\hline Bra13 & $8.21 \mathrm{gh}$ & $13.2^{\mathrm{m}}$ & $5.80^{\mathrm{ab}}$ & $2.02 \mathrm{hi}$ & $28.4^{b c}$ & $8.00^{b c}$ & $238^{b}$ & n.d. \\
\hline Bra25 & $7.63 \mathrm{hi}$ & $14.1^{\mathrm{kl}}$ & $4.58^{\mathrm{cd}}$ & $1.95^{\mathrm{ij}}$ & $18.9^{\mathrm{fg}}$ & $9.43^{a b}$ & $267^{b}$ & n.d. \\
\hline Bra30 & $4.32^{\circ}$ & $11.5^{\mathrm{n}}$ & $4.13^{\mathrm{de}}$ & $2.83^{\mathrm{ab}}$ & $21.7^{\mathrm{cd}}$ & $7.09 \mathrm{~cd}$ & n.d. & $0.87^{\mathrm{c}}$ \\
\hline Bra32 & $5.83^{\mathrm{lm}}$ & $14.4^{\mathrm{kl}}$ & $6.20^{\mathrm{a}}$ & $2.85^{\mathrm{ab}}$ & $17.5^{\mathrm{fg}}$ & $9.19^{a b}$ & $376^{\mathrm{ab}}$ & $8.11^{b}$ \\
\hline Bra33 & $9.06^{\mathrm{cd}}$ & $13.6^{\mathrm{lm}}$ & 4.21 de & $1.23^{\mathrm{m}}$ & $17.4^{\mathrm{fg}}$ & $7.09 \mathrm{~cd}$ & $348^{a b}$ & n.d. \\
\hline Bra51 & $7.07^{\mathrm{ij}}$ & $15.4^{\mathrm{ij}}$ & 4.44 de & 2.05 hi & $20.2^{\text {de }}$ & $6.70 \mathrm{de}$ & $284^{b}$ & $0.32^{c}$ \\
\hline Bra53 & $10.9^{b c}$ & $17.1^{\mathrm{gh}}$ & $6.04^{\mathrm{a}}$ & 2.22 ef & 19.8 ef & $11.4^{\mathrm{ab}}$ & n.d. & n.d. \\
\hline Bra54 & $10.6^{\mathrm{bc}}$ & $13.6^{\mathrm{lm}}$ & $4.08^{\mathrm{de}}$ & 2.32 ef & $32.0^{b c}$ & $12.0^{\mathrm{ab}}$ & $209^{b c}$ & $6.53^{b}$ \\
\hline Bra66 & $9.54^{\mathrm{cd}}$ & $24.5^{b c}$ & 3.12 hi & $2.97^{\mathrm{a}}$ & $31.4^{b c}$ & $9.31^{\mathrm{ab}}$ & $239^{b}$ & $0.32^{c}$ \\
\hline Bra78 & $10.3^{b c}$ & 15.9 hi & $5.61^{\mathrm{ab}}$ & $2.55^{b c}$ & $32.8^{b c}$ & $9.45^{\mathrm{ab}}$ & $131^{\mathrm{c}}$ & n.d. \\
\hline Bra79 & $9.52^{\mathrm{cd}}$ & $25.1^{b}$ & $1.04^{1}$ & 2.36 ef & $22.8^{\mathrm{cd}}$ & $11.5^{\mathrm{ab}}$ & n.d. & n.d. \\
\hline Bra80 & 7.39 ij & $14.2^{\mathrm{kl}}$ & $3.44 \mathrm{fg}$ & $2.48^{\mathrm{cd}}$ & $31.3^{b c}$ & $13.0^{\mathrm{a}}$ & $427^{a}$ & n.d. \\
\hline Hon 86 & $9.05^{\mathrm{cd}}$ & $23.7^{\mathrm{c}}$ & $2.08^{\mathrm{k}}$ & 2.27 ef & $26.2^{b c}$ & $10.2^{\mathrm{ab}}$ & $222^{b}$ & $57.5^{a}$ \\
\hline IT41 & 8.89 de & $21.6^{\mathrm{d}}$ & $2.59 \mathrm{ij}$ & $2.26^{\text {ef }}$ & $26.3^{b c}$ & $7.81^{b c}$ & $193^{b c}$ & n.d. \\
\hline IT42 & $8.55^{\text {ef }}$ & $21.4^{\text {de }}$ & $5.26^{b c}$ & $1.74 \mathrm{kl}$ & $12.9^{\mathrm{h}}$ & $7.09 \mathrm{~cd}$ & $444^{\mathrm{a}}$ & $1.34^{\mathrm{c}}$ \\
\hline IT43 & $11.0^{\mathrm{ab}}$ & $27.9^{a}$ & $1.01^{1}$ & $2.73^{a b}$ & $19.1^{\mathrm{fg}}$ & $8.11^{b c}$ & n.d. & n.d. \\
\hline IT44 & $10.5^{b c}$ & $16.5^{\mathrm{hi}}$ & $3.23 \mathrm{gh}$ & $1.49^{\mathrm{lm}}$ & $32.6^{b c}$ & $8.85^{\mathrm{ab}}$ & $155^{c}$ & n.d. \\
\hline IT46 & $7.30^{\mathrm{ij}}$ & $19.4^{\mathrm{f}}$ & $6.00^{\mathrm{a}}$ & $1.36^{\mathrm{m}}$ & $23.4^{\mathrm{cd}}$ & $7.04 \mathrm{~cd}$ & n.d. & n.d. \\
\hline IT47 & $6.04^{\mathrm{lm}}$ & $13.6^{\mathrm{lm}}$ & $2.99 \mathrm{hi}$ & $2.18^{\mathrm{fg}}$ & $25.4^{b c}$ & $7.74^{b c}$ & n.d. & n.d. \\
\hline IT48 & $6.38^{\mathrm{kl}}$ & $15.2^{\mathrm{ij}}$ & $3.26^{\mathrm{gh}}$ & $2.45^{\mathrm{de}}$ & $27.0^{b c}$ & $8.94^{\mathrm{ab}}$ & $207^{b c}$ & n.d. \\
\hline IT49 & $4.84^{\text {no }}$ & $13.2^{\mathrm{m}}$ & $4.74^{\mathrm{cd}}$ & $2.18^{\mathrm{fg}}$ & $23.3^{\mathrm{cd}}$ & $5.93^{\mathrm{e}}$ & $105^{\mathrm{d}}$ & $1.97^{\mathrm{c}}$ \\
\hline IT81 & $6.47^{\mathrm{jk}}$ & $24.5^{b c}$ & $2.56^{\mathrm{ij}}$ & $2.11^{\mathrm{gh}}$ & $32.5^{b c}$ & $8.70^{a b}$ & $230^{b}$ & n.d. \\
\hline IT82 & $8.36^{\mathrm{fg}}$ & $24.4^{b c}$ & $2.46^{j \mathrm{k}}$ & 2.33 ef & $26.0^{b c}$ & $7.61^{b c}$ & $233^{b}$ & n.d. \\
\hline IT83 & 8.63 de & $19.2^{\mathrm{f}}$ & 3.94 ef & $2.11 \mathrm{gh}$ & $37.3^{\mathrm{ab}}$ & $10.0^{\mathrm{ab}}$ & $162^{\mathrm{c}}$ & n.d. \\
\hline IT84 & $5.47 \mathrm{mn}$ & $10.8^{n}$ & 3.89 ef & $1.85^{\mathrm{jk}}$ & $46.0^{\mathrm{a}}$ & $11.1^{\mathrm{ab}}$ & $292^{b}$ & n.d. \\
\hline USA45 & $11.2^{\mathrm{a}}$ & $14.7^{\mathrm{jk}}$ & $5.90^{\mathrm{ab}}$ & 2.29 ef & $29.0^{b c}$ & $8.11^{b c}$ & $59.0^{\mathrm{e}}$ & n.d. \\
\hline USA85 & $6.40 \mathrm{kl}$ & $17.9 \mathrm{~g}$ & $3.12 \mathrm{hi}$ & $1.83^{\mathrm{jk}}$ & $24.2^{\mathrm{cd}}$ & $10.1^{\mathrm{ab}}$ & $142^{c}$ & n.d. \\
\hline
\end{tabular}

Within each parameter, values without common letters significantly differed at $p<0.05$ according to Tukey's HSD test. . $d=$ not detected.

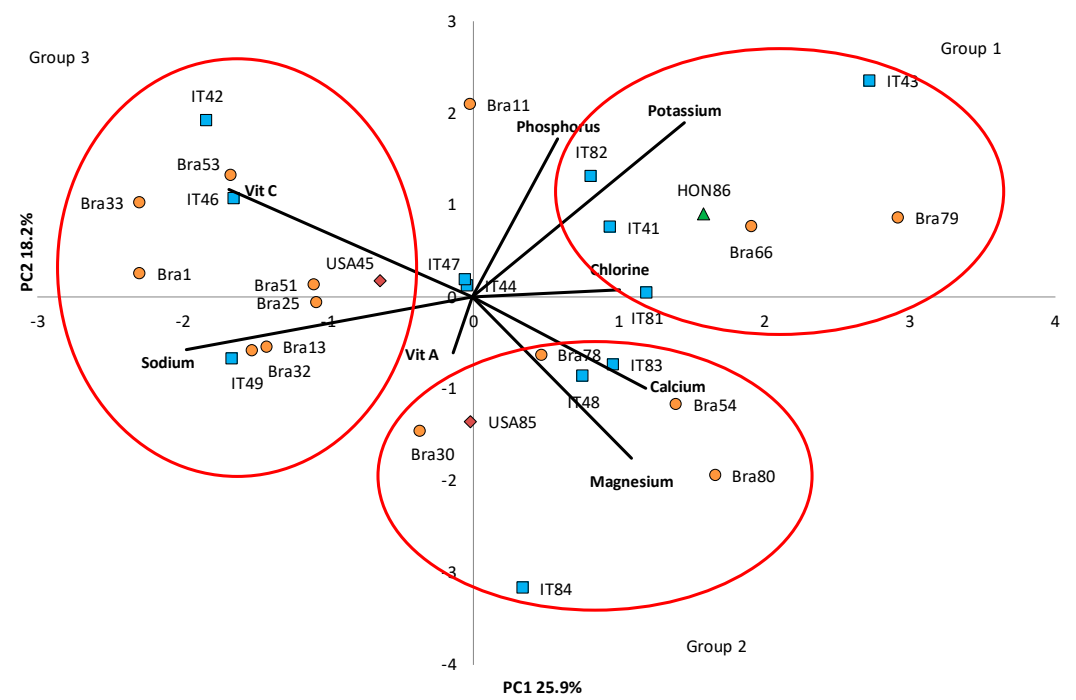

Figure 2. Principal components analysis (PCA) of the sweet potato core collection based on qualitative traits and their contribution to the daily nutritional intake according to adults' needs (European Food Safety Agency standards). Genotypes origin: $\triangle$ Honduras; $\diamond$ United States; $\square$ Italy; ○ Brazil. 


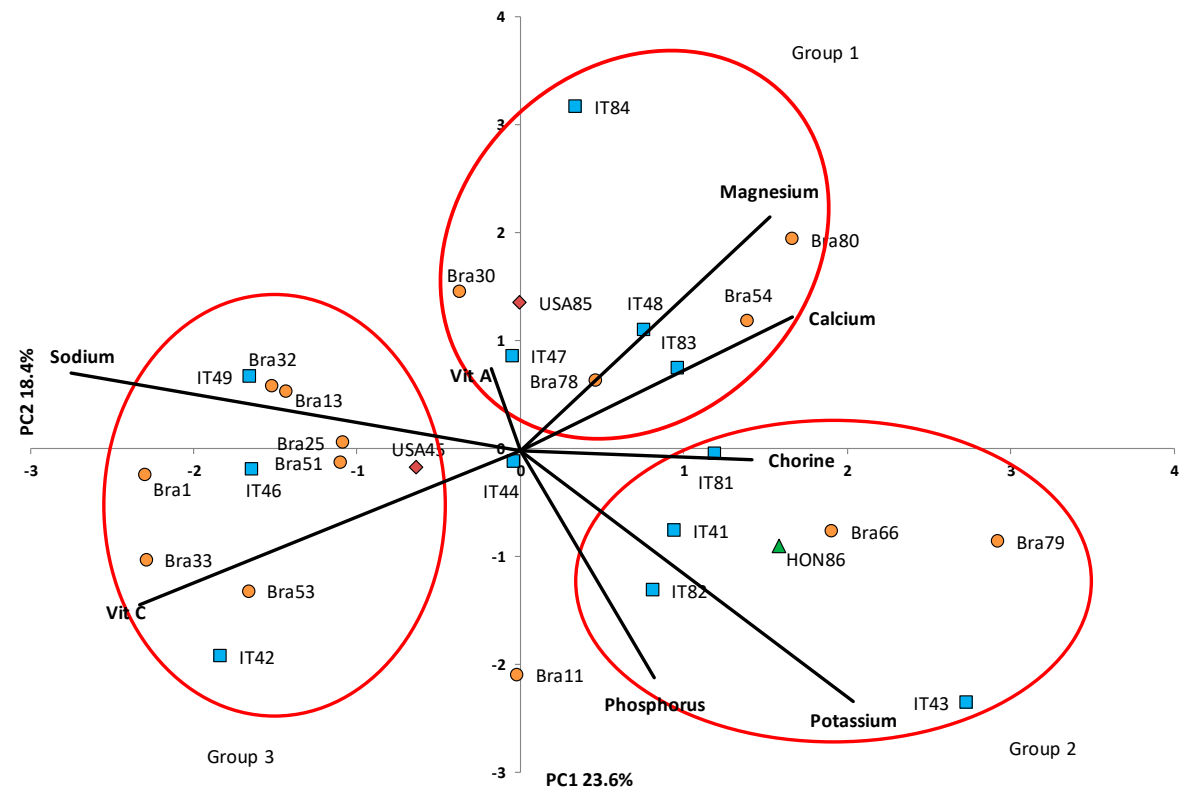

Figure 3. Principal components analysis (PCA) of the sweet potato core collection based on qualitative traits and their contribution to the daily nutritional intake according to children's needs (European Food Safety Agency standards). Genotypes origin: $\Delta$ Honduras; $\diamond$ United States; $\square$ Italy; $\bigcirc$ Brazil.

\section{Discussion}

The overall nutritional picture that emerged from this work highlights the high potential that SP can offer the consumer in relation to the accession. From a qualitative point of view, the content of starch and soluble sugars represents a relevant aspect considering that the carbohydrate content is directly linked to the sensory aspects that characterize this product.

Roots of SPs are generally stored before the commercialization to increase their sweetness index, so the content of the main metabolic sugars such as glucose, sucrose, and fructose can be influenced either by post-harvest conditions or by the specific physiology of every accession. Indeed, sugar composition is specific to every accession. Sucrose and starch are largely responsible for the post-harvest behavior and the taste of the SP. The cooking procedure can further modify the sugar composition [19]. Conversely, four breeding lines and five commercial varieties of SPs analyzed by Lewthwaite et al. [20], showed that orange-fleshed SPs had a higher content of glucose and fructose compared to the others. Similarly, Agnes et al. [21] found a relationship between sucrose content and color of the flesh: the white-fleshed SP contained less sucrose than the orange-fleshed SP and yellow-fleshed SP. An opposite trend was found for the glucose and fructose contents, as well. Sucrose content is also a physiological signal for the formation of storage roots because there is a trigger of several genes involved in the tissue differentiation. Besides, sucrose is loaded in root cells, and it is converted to hexoses inside amyloplasts and stored as starch. Cervantes-Flores et al. [22] demonstrated that SPs varieties with orange-flesh have lower concentrations of starch. According to them, the concentration of starch and the amount of $\beta$-carotene are inversely related, most likely because these two substances compete for the synthesizing sites in the plastids. Our data are in agreement with these findings as the orange genotype Hon 86 was characterized by a lower starch content.

The low content of soluble sugars slows the retrogradation of starch, improving the texture after cooking [23]. The genotypes with a lower content of total sugars were Bra33, USA45, and IT48, therefore, they could be used by the food processing industry because the low content of soluble sugars increases the shelf life [24]. As a high amount of sugar can affect the final color and the texture of the food, high levels of simple sugars can interfere with the starch hydration due to the competition with the starch for free water in the flourwater system. During cooking at high temperature, the free sugars interact with proteins 
and confer brown coloration during the process of caramelization. The dehydration of the carbohydrates at high temperatures provides characteristic color and flavor. Therefore, due to the proportion of sugars, Bra51, Hon86, Bra32, and IT43, could be suitable for frying. It is strategic for the food industry to also consider the ratio of sugars and the starch content of SP roots because these properties can change the chemical-physical properties of the food. The accessions of SP with high starch content, low total sugar, and high dry matter content are suitable for frying, roasting, or baking [21]. Overall, USA45 and Bra33 have interesting characteristics for home cooking. Concerning the dry matter, the values varied between $29.5 \%$ and $43.1 \%$ and are in line with what was reported by Ellong et al. [25], but higher than that found by Laurie et al. [26] in other genotypes. Therefore, considering the values detected in this experiment, it seems useful to use the classification proposed by Truong et al. [27] which allows to identify all genotypes with a percentage of dry matter higher than $30 \%$ as "dry", whereas the BRA51 genotype can be classified as "intermediate".

Cooking methods can influence the nutrient retention of raw SPs, therefore it is essential to use the correct cooking system to maintain as much as possible the nutritional values that the product is able to offer, especially for phenols, vitamin C, or carotenoids. This aspect should be considered for the estimation of the percent of contribution to DV. Several studies have demonstrated that high retention of total carotenoids is reached by using oven drying, with losses ranging from 10 to $4 \%$ compared to the raw product. The boiling and the frying processes are characterized by a carotenoid loss from $15 \%$ to $10 \%$ and from $23 \%$ to $15 \%$, respectively [28]. The preservation of carotenoids is essential, as they are linked to protective effects against the mutagenic activity and free radicals [29]. Indeed, regular consumption of food rich in phenols, such as fruits and vegetables, can contribute to the prevention of several diseases, such as cardiac pathology, cancer, and infections [30-32]. Heating can affect the content of the phenolic compounds and antioxidants because the temperature affects the structure of the cells which then release pigments from the cell wall [33]. Nicoletto et al. [19] measured the effect of the cooking process on the qualitative traits of SP and demonstrated an increase in the total phenol and antioxidant capacity content after cooking. For instance, the fried samples had 78\% higher antioxidants content than raw samples. Indeed, Padda and Picha [14] compared the phenolic and antioxidant activity and found a similar difference among the $14 \mathrm{SP}$ varieties tested. Our results agree with previous studies, where purple-flashed SPs had a higher amount of phenolic compounds $[14,16,34]$. The same varieties showed a higher amount of these compounds and the cream- and white-fleshed varieties had a lower content. The genetic variability of the genotypes may be the cause of the variation in phenolic content. The vegetables with red or purple-blue color had a high amount of phenolic and antioxidant compounds, and the levels of some accessions of SPs are comparable to those found in strawberries and blackberries [34].

According to the World Health Organization (WHO), as reported by Stone et al. [35], an insufficient intake of minerals is one of the main risks for human health worldwide. In some countries, the occurrence of this problem is driven by the resource shortages, becoming a leading concern to public health. Significant steps are being taken to address malnutrition: globally, stunting among children under the age of five decreased from $32.6 \%$ in 2000 to $22.2 \%$ in 2017, whereas there was a slight decrease in underweight women from $11.6 \%$ in 2000 to $9.7 \%$ in 2016. However, this slow and piecemeal improvement must be pursued further. It should also be considered that the consumption of SP can improve the health of consumers even in developed countries, especially with regard to food with high fiber and a low or medium glycemic index, which can be beneficial for diabetic or insulin-resistant consumers [36]. Moreover, dietary fiber can play an important role in human health revealing a good relationship with the incidence of constipation, obesity, cardiovascular diseases, colon cancer, and diabetes mellitus [37-39]. The diary intake of food with a high antioxidant, phenols, and vitamin contents could be a possible solution for those consuming nutritionally deficient diets. 
The WHO and the Europe Food Safety Authority (EFSA) have guidelines for nutrients ingest and the level of necessary intake to satisfy the daily demand for healthy nutrients. For instance, phosphorus plays a role in the metabolism of carbohydrates and fats, making it indispensable for the human body; potassium participates in the osmoregulation of cells, and its absorption by the body is about $90 \%$ [35]. According to these aspects, it is important to highlight that some of the accessions considered in this trial can provide a significant amount of phosphorus and potassium such as IT43 and IT81, respectively. Vitamin C, an essential and well-known antioxidant that protects cells against free radical damage, can be supplied in a high amount in SPs. Ten out of the 29 accessions tested in this experiment can fully provide the daily intake by eating a $100 \mathrm{~g}$ portion. The assimilation of Vitamin $C$ is high and, during digestion, up to $70-90 \%$ is absorbed [40].

Vitamin A is a group of fat-soluble compounds including retinol, retinal, and some esters; it plays a fundamental role in the visual system, immunity, and maintenance of the cells' function. The human body needs a small amount but cannot synthesize it. The demands are more critical in infancy, adolescence, and pregnancy/lactation [41], and vitamin A deficiency is an essential matter in developing countries. Despite the losses due to the cooking process, about $26 \%$ [42] of the orange-fleshed SPs showed a higher contribution to the DV. These results agree with those of Burri [43], Huang et al. [42], and Tumwegamire et al. [44]. Therefore, SP can be a considerable a valuable source for a vitamin A deficient population. For example, Burri [43] calculated that one person needs to eat only half a cup of orange-fleshed SP to supply $100 \%$ DV of vitamin A. In accordance with what was found by Palumbo et al. [45], the content of vitamin C and vitamin A does not appear to be linked to high concentrations of potassium and calcium, as it is well shown in Figures 2 and 3.

\section{Conclusions}

According to the obtained data, the consumption of SP could help the intake of phosphorous, potassium, magnesium, calcium, vitamin C, and vitamin A. In particular, orange- and purple-fleshed SPs provide a significant antioxidant and vitamin contribution to the human diet. SP is a staple food in many countries and breeding it to fortify some nutritional values could be the key to enhance the diet value of populations in many regions of the world. In Europe, the growing demand for this product has attracted farmers who are now looking for new opportunities. SP crop production in temperate zones is quite recent, and research is limited. This study has attempted to give guidelines from a nutritional point of view for further research in order to expand both production and consumption of SPs in Europe. Some interesting accessions for consumption were highlighted, in particular USA45 and Bra33, whereas Bra33, USA45, and IT48 showed great traits of their potential use by the food processing industry.

These sweet potato accessions can improve the daily intake of minerals in the diet giving guidelines for deeper research and to expand the production and consumption of sweet potatoes in Europe.

Author Contributions: Conceptualization, A.C.G., C.N., P.S., and P.F.V.; methodology, A.C.G. and C.N.; software, A.C.G. and C.N.; validation, A.C.G. and C.N.; formal analysis, A.C.G., C.N., and G.Z.; investigation, A.C.G. and C.N.; resources, P.S.; data curation, A.C.G. and C.N.; writingoriginal draft preparation, A.C.G. and C.N.; writing—review and editing, A.C.G., C.N., G.Z., P.S., and P.F.V.; supervision, P.S.; project administration, P.S.; funding acquisition, P.S. All authors have read and agreed to the published version of the manuscript.

Funding: This research received no external funding.

Institutional Review Board Statement: Not applicable.

Informed Consent Statement: Not applicable.

Conflicts of Interest: The authors declare no conflict of interest. 


\section{References}

1. Mussoline, W.A.; Wilkie, A.C. Feed and fuel: The dual-purpose advantage of an industrial sweetpotato. J. Sci. Food Agric. 2017, 97, 1567-1575. [CrossRef]

2. Low, J.; Ball, A.; Magezi, S.; Njoku, J.; Mwanga, R.; Andrade, M.; van Mourik, T. Sweet potato development and delivery in sub-Saharan Africa. Afr. J. Food Agric. Nutr. Dev. 2017, 17, 11955-11972. [CrossRef]

3. FAOSTAT. 2019. Crop Production Statistics. 2018. Available online: http://faostat3.fao.org/home/E (accessed on 30 December 2020).

4. Altemimi, A.B. Extraction and Optimization of Potato Starch and Its Application as a Stabilizer in Yogurt Manufacturing. Foods 2018, 7, 14. [CrossRef]

5. CBI Market Intelligence. CBI Product Factsheet Fresh Sweet Potatoes in Europe. 2015. Available online: https://it.scribd.com/ document/326237170/Product-Factsheet-Europe-Fresh-Sweet-Potatoes-2015 (accessed on 30 December 2020).

6. Neela, S.; Fanta, S.W. Review on nutritional composition of orange-fleshed sweet potato and its role in management of vitamin A deficiency. Food Sci. Nutr. 2019, 7, 1920-1945. [CrossRef]

7. Cartier, A.; Woods, J.; Sismour, E.; Allen, J.; Ford, E.; Githinji, L.; Xu, Y. Physiochemical, nutritional and antioxidant properties of fourteen Virginia-grown sweet potato varieties. J. Food Meas. Charact. 2017, 11, 1333-1341. [CrossRef]

8. Bruins, M.J.; Bird, J.K.; Aebischer, C.P.; Eggersdorfer, M. Considerations for Secondary Prevention of Nutritional Deficiencies in High-Risk Groups in High-Income Countries. Nutrients 2018, 10, 47. [CrossRef]

9. Kehoe, L.; Walton, J.; Flynn, A. Nutritional challenges for older adults in Europe: Current status and future directions. Proc. Nutr. Soc. 2019, 78, 1-13. [CrossRef]

10. Lockyer, S.; White, A.; Buttriss, J.L. Biofortified crops for tackling micronutrient deficiencies-what impact are these having in developing countries and could they be of relevance within Europe? Nutr. Bull. 2018, 43, 319-357. [CrossRef]

11. Islam, S.N.; Nusrat, T.; Begum, P.; Ahsan, M. Carotenoids and $\beta$-carotene in orange fleshed sweet potato: A possible solution to vitamin A deficiency. Food Chem. 2016, 199, 628-631. [CrossRef]

12. Zhao, J.-G.; Yan, Q.-Q.; Lu, L.-Z.; Zhang, Y.Q. In vivoantioxidant, hypoglycemic, and anti-tumor activities of anthocyanin extracts from purple sweet potato. Nutr. Res. Pr. 2013, 7, 359-365. [CrossRef]

13. Salawu, S.O.; Udi, E.; Akindahunsi, A.A.; Boligon, A.A.; Athayde, M.L. Antioxidant potential, phenolic profile and nutrient composition of flesh and peels from Nigerian white and purple skinned sweet potato (Ipomea batatas L.). Asian J. Plant. Sci. 2015, 5, 14-23.

14. Padda, M.S.; Picha, D.H. Quantification of phenolic acids and antioxidant activity in sweetpotato genotypes. Sci. Hortic. 2008, 119, 17-20. [CrossRef]

15. Ji, H.; Zhang, H.; Li, H.; Li, Y. Analysis on the Nutrition Composition and Antioxidant Activity of Different Types of Sweet Potato Cultivars. Food Nutr. Sci. 2015, 6, 161-167. [CrossRef]

16. Teow, C.C.; Truong, V.-D.; McFeeters, R.F.; Thompson, R.L.; Pecota, K.V.; Yencho, G.C. Antioxidant activities, phenolic and $\beta$-carotene contents of sweet potato genotypes with varying flesh colours. Food Chem. 2007, 103, 829-838. [CrossRef]

17. Xu, F.; Yuan, Q.P.; Dong, H.R. Determination of lycopene and \& beta-carotene by high-performance liquid chromatography using sudan I as internal standard. J. Chromatogr. B 2006, 838, 44-49. [CrossRef]

18. Barba, A.O.I.; Hurtado, M.C.; Mata, M.S.; Ruiz, V.F.; De Tejada, M.L.S. Application of a UV-vis detection-HPLC method for a rapid determination of lycopene and $\beta$-carotene in vegetables. Food Chem. 2006, 95, 328-336. [CrossRef]

19. Nicoletto, C.; Vianello, F.; Sambo, P. Effect of different home-cooking methods on textural and nutritional properties of sweet potato genotypes grown in temperate climate conditions. J. Sci. Food Agric. 2018, 98, 574-581. [CrossRef]

20. Lewthwaite, S.L.; Sutton, K.H.; Triggs, C.M. Free sugar composition of sweetpotato cultivars after storage. N. Z. J. Crop. Hortic. Sci. 1997, 25, 33-41. [CrossRef]

21. Agnes, N.; Agnes, N.; Yusuf, B.; Judith, N.; Trude, W. Potential use of selected sweetpotato (Ipomea batatas Lam) varieties as defined by chemical and flour pasting characteristics. Food Nutr. Sci. 2012, 3, 889-896.

22. Cervantes-Flores, J.C.; Sosinski, B.; Pecota, K.V.; Mwanga, R.O.M.; Catignani, G.L.; Truong, V.D.; Watkins, R.H.; Ulmer, M.R.; Yencho, G.C. Identification of quantitative trait loci for dry-matter, starch, and $\beta$-carotene content in sweetpotato. Mol. Breed. 2011, 28, 201-216. [CrossRef]

23. Kohyama, K.; Nishinari, K. Effect of soluble sugars on gelatinization and retrogradation of sweet potato starch. J. Agric. Food Chem. 1991, 39, 1406-1410. [CrossRef]

24. Chang, S.-M.; Liu, L.-C. Retrogradation of Rice Starches Studied by Differential Scanning Calorimetry and Influence of Sugars, $\mathrm{NaCl}$ and Lipids. J. Food Sci. 1991, 56, 564-566. [CrossRef]

25. Ellong, E.N.; Billard, C.; Adenet, S. Comparison of Physicochemical, Organoleptic and Nutritional Abilities of Eight Sweet Potato (Ipomoea batatas) Varieties. Food Nutr. Sci. 2014, 5, 196-311. [CrossRef]

26. Laurie, S.M.; van Jaarsveld, P.J.; Faber, M.; Philpott, M.F.; Labuschagne, M.T. Trans-b-carotene, selected mineral content and potential nutritional contribution of 12 sweet potato varieties. J. Food Compost. Anal. 2012, 27, 151-159. [CrossRef]

27. Truong, V.D.; Hamann, D.D.; Walter, W.M. Relationship between instrumental and sensory parameters of cooked sweetpotato texture. J. Texture Stud. 1997, 28, 163-185. [CrossRef]

28. Vimala, B.; Nambisan, B.; Hariprakash, B. Retention of carotenoids in orange-fleshed sweet potato during processing. J. Food Sci. Technol. 2011, 48, 520-524. [CrossRef] 
29. Rumbaoa, R.G.O.; Cornago, D.F.; Geronimo, I.M. Phenolic content and antioxidant capacity of Philippine sweet potato (Ipomoea batatas) varieties. Food Chem. 2009, 113, 1133-1138. [CrossRef]

30. Giglio, R.V.; Patti, A.M.; Cicero, A.F.; Lippi, G.; Rizzo, M.; Toth, P.P.; Banach, M. Polyphenols: Potential Use in the Prevention and Treatment of Cardiovascular Diseases. Curr. Pharm. Des. 2018, 24, 239-258. [CrossRef]

31. Li, S.; Tan, H.-Y.; Wang, N.; Cheung, F.; Hong, M.; Feng, Y. The Potential and Action Mechanism of Polyphenols in the Treatment of Liver Diseases. Oxidative Med. Cell. Longev. 2018, 2018, 1-25. [CrossRef]

32. Oak, M.-H.; Auger, C.; Belcastro, E.; Park, S.-H.; Lee, H.-H.; Schini-Kerth, V.B. Potential mechanisms underlying cardiovascular protection by polyphenols: Role of the endothelium. Free. Radic. Biol. Med. 2018, 122, 161-170. [CrossRef]

33. Huang, Y.-C.; Chang, Y.-H.; Shao, Y.-Y. Effects of genotype and treatment on the antioxidant activity of sweet potato in Taiwan. Food Chem. 2006, 98, 529-538. [CrossRef]

34. Cevallos-Casals, B.A.; Cisneros-Zevallos, L. Stoichiometric and kinetic studies of phenolic antioxidants from Andean purple corn and red-fleshed sweetpotato. J. Agric. Food Chem. 2003, 51, 3313-3319. [CrossRef]

35. Stone, M.S.; Martyn, L.; Weaver, C.M. Potassium Intake, Bioavailability, Hypertension, and Glucose Control. Nutrients 2016, 8, 444. [CrossRef]

36. Allen, C.J.; Corbitt, D.A.; Maloney, P.K.; Butt, S.M.; Truong, V.D. Glycemic index of sweet potato as affected by cooking methods. Open Nutr. J. 2012, 6, 1-11. [CrossRef]

37. Redondo-Cuenca, A.; Villanueva-Suárez, M.J.; Rodríguez-Sevilla, M.D.; Mateos-Aparicio, I. Chemical composition and dietary fibre of yellow and green commercial soybeans (Glycine max). Food Chem. 2007, 101, 1216-1222. [CrossRef]

38. Mei, X.; Mu, T.-H.; Han, J.-J. Composition and Physicochemical Properties of Dietary Fiber Extracted from Residues of 10 Varieties of Sweet Potato by a Sieving Method. J. Agric. Food Chem. 2010, 58, 7305-7310. [CrossRef]

39. Yoshimoto, M.; Yamakawa, O.; Tanoue, H. Potential Chemopreventive Properties and Varietal Difference of Dietary Fiber from Sweetpotato (Ipomoea batatas L.) Root. Jpn. Agric. Res. Quarterly 2005, 39, 37-43. [CrossRef]

40. World Health Organization. Global Prevalence of Vitamin a Deficiency in Populations at Risk 1995-2005: WHO Global Database on Vitamin a Deficiency; WHO Press: Geneva, Switzerland, 2009; Volume 55, ISBN 9789241598019.

41. Almeida, L.B.; Penteado, M.V. Carotenoids and pro-vitamin A value of white fleshed Brazilian sweet potatoes (Ipomoea batatas Lam.). J. Food Compos. Anal. 1988, 1, 341-352. [CrossRef]

42. Huang, A.S.; Tanudjaja, L.; Lum, D. Content of Alpha-, Beta-Carotene, and Dietary Fiber in 18 Sweetpotato Varieties Grown in Hawaii. J. Food Compos. Anal. 1999, 12, 147-151. [CrossRef]

43. Burri, B.J. Evaluating Sweet Potato as an Intervention Food to Prevent Vitamin A Deficiency. Compr. Rev. Food Sci. Food Saf. 2011, 10, 118-130. [CrossRef]

44. Tumwegamire, S.; Kapinga, R.; Rubaihayo, P.R.; LaBonte, D.R.; Grüneberg, W.J.; Burgos, G.; Felde, T.Z.; Carpio, R.; Pawelzik, E.; Mwanga, R.O. Evaluation of Dry Matter, Protein, Starch, Sucrose, $\beta$-carotene, Iron, Zinc, Calcium, and Magnesium in East African Sweetpotato [Ipomoea batatas (L.) Lam] Germplasm. HortScience 2011, 46, 348-357. [CrossRef]

45. Palumbo, F.; Galvao, A.C.; Nicoletto, C.; Sambo, P.; Barcaccia, G. Diversity Analysis of Sweet Potato Genetic Resources Using Morphological and Qualitative Traits and Molecular Markers. Genes 2019, 10, 840. [CrossRef] [PubMed] 